\title{
UNASUR: Regional Pluralism as a Strategic Outcome
}

\author{
Detlef Nolte* \\ Nicolás Matías Comini ${ }^{* *}$
}

\begin{abstract}
South America features a very particular regional architecture, one which is characterised by the proliferation and overlapping of regional organisations, with UNASUR at the centre. UNASUR is an intergovernmental organisation with no supranational institutions. The article will argue that institutional flexibility, which is both a core element of South American regionalism and a specific institutional feature of UNASUR, corresponds with the key interests of the founding members of this organisation. Based on this assumption, the article will analyse the strategies and policies of the various Argentinean governments during the period when UNASUR was created (19992008). It will differentiate between a 'uniaxial' regional integration approach structured around one thematic axis and a 'multiaxial' approach evolving along multiple axes in parallel; it will also ask to what extent the new regional architecture corresponds to the core interests of that country. For the Argentinean government, it was important to ensure that UNASUR would not constrain its foreign policy options. The result was the variable geometry codified in the UNASUR Constitutive Treaty.
\end{abstract}

Keywords: Regionalism; Integration; UNASUR; South America; Argentina.

\section{Introduction}

The Union of South American Nations (UNASUR) was first shaped by Brazil, and reflects Itamaraty's own core interests and goals. While this interpretation is essentially correct, it parts from the assumption that the remaining eleven South American countries merely adapted their respective positions to what the government of Lula da Silva wanted to do in regional integration terms. This premise is empirically refutable. The road to the creation of UNASUR, and the factors that explain the form it ultimately took, were in fact much more complex than this.

Parting from an institutionalist perspective, UNASUR is interpreted as an organisation that contributes to regional segmentation. From this point of view, the South American countries' inability to build solid regional institutions stimulates the creation of new

\footnotetext{
* GIGA German Institute and University of Hamburg, Hamburg, Germany: detlef.nolte@giga-hamburg.de.

** Universidad del Salvador, Buenos Aires, Argentina, and GIGA German Institute, Hamburg, Germany: nicolas.comini@usal.edu.ar.
} 
entities. As a new organisation responding to the Brazilian ambition of becoming a regional leader, UNASUR reinforces the overlapping of regional organisations. Its entrance into a regional architecture already packed with institutions - such as OAS, MERCOSUR, Andean Community, Rio Group, or ALADI - generated friction both between and within them. It was thus a symptom of division, not of unity. 'Asistimos a una sucesión de cumbres, tantas que parece una cordillera, complained the Chilean President Sebastián Piñera in 2011 (La Información 2011).

This article starts from an alternative point of view. From a political-strategic and foreign policy perspective, it considers UNASUR as an additional element in the South American regional architecture. The block was set up because twelve South American countries wanted it to happen. Both its institutional profile and agenda were the result of a collective decision being made. UNASUR was what the governments of the constituent member countries wanted it to be. All governments must have found something in that project that was of interest to them. Its formation was not a harmonious or linear process. On the contrary, it was a drawn out one characterised by moments of both convergence and divergence. UNASUR created an additional space for dialogue and co-operation within a system that had already provided several alternative arenas for action that vary according to the actors and issues areas involved.

In the Argentinean case, taking a political-strategic perspective makes sense. Notwithstanding the fact that, from 1999 onward, the country's various governments had been reluctant to support the South Americanisation of regional integration, in 2008 President Cristina Fernández de Kirchner still signed the Constitutive Treaty of UNASUR. This did not happen because President Lula forced his counterpart to put pen to paper. On the contrary, it was the result of a long negotiation process in which the Argentinean government looked for guarantees that UNASUR's institutional design and multiaxial profile would allow it to develop its own regional cooperation and integration agenda without major restrictions being placed on the definition of its foreign policy goals. With this decision, Argentina prioritised the likelihood that this new organisation would constitute an additional platform from which to influence the regional agenda.

The article is divided into five sections. The first gives an overview of the debate over the proliferation and overlapping of regional organisations in Latin America. The second discusses the concept of regional integration. The third and fourth sections then analyse the chosen position and strategy of the Argentinean government in the formation and construction of the current regional architecture in South America, with a special focus on UNASUR and the interaction of this new South American organisation with other regional actors, organisations, and projects. Within these sections, the analysis will differentiate between a 'uniaxial' and a 'multiaxial' regional integration approach. A brief conclusion summarises to what extent the current regional architecture in South America can be said to reflect the interests and foreign policy priorities of Argentina. While UNASUR is perceived as an additional regional forum for cooperation on issue areas such as defence, infrastructure, health, science and technology, or finance, MERCOSUR is still the cornerstone of Argentina's regional integration strategy. 


\section{Segmented regionalism versus institutional flexibility}

Most world regions feature more than one regional organisation. Often, these organisations are complementary and perform different functions. Some are sub-organisations of other or wider-ranging regional organisations. However, regional organisations can also overlap with regard to their mandates and constituent members (for Africa, see Genna and De Lombaerde 2010; for Latin America, Malamud 2013; Weiffen et al. 2013; Malamud and Gardini 2012). The proliferation and overlapping of regional organisations is frequently described and symbolised by invoking the metaphor of a spaghetti bowl. Such spaghetti concoctions are dished up by scholars in African, Asian, Latin American, and even European bowls.

As to the Latin American spaghetti bowl, both the proliferation and the overlapping of regional organisations, as well the possible consequences thereof, have been broadly discussed. One group of analysts - best represented by Malamud and Gardini (2012) take a very critical view of this. They state that 'the presence of segmented and overlapping regionalist projects is not a manifestation of successful integration but, on the contrary, signals the exhaustion of its potential' (Malamud and Gardini 2012: 117). In their opinion, the multiple memberships of states in different (sub)regional organisations will invariably create friction between and within regional integration projects - and thus will ultimately fuel division instead of unity in the region. Moreover, as Gómez-Mera (2015: 20) indicates, 'by introducing legal fragmentation and rule ambiguity, regime complexity has exacerbated implementation and compliance problems in Latin American regional cooperation initiatives.'

Figure 1: UNASUR - Organisational perspective

\section{UNASUR}

\section{O R G A N I Z A T I O N A L P E R S P E C T I V E}

UNASUR: As disruptive factor in the Latin American institutional architecture

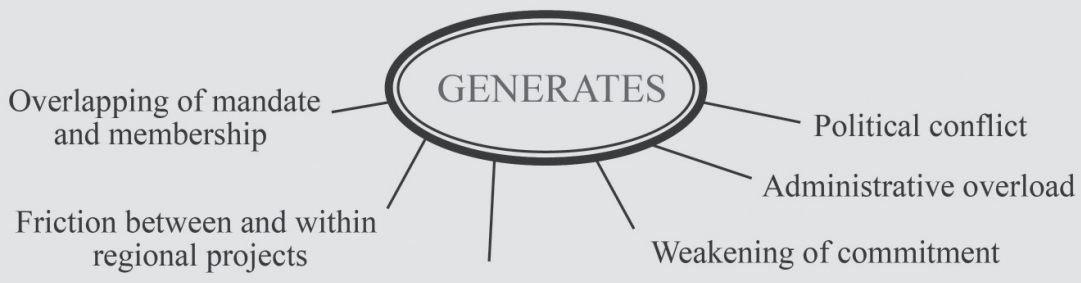

Division in the region

Source: Authors' own elaboration. 
While Malamud and Gardini (2012) and Gómez-Mera (2015) focus on the risks related to the proliferation and overlapping of regional organisations in Latin America, for other authors (Riggirozzi and Tussie 2012; Tussie 2009; Sanahuja 2010) it is still not clear how the regional architecture will evolve and what the emergence of a multifaceted pattern of overlapping regional organisations and projects will come to imply. 'The trend may be not towards amalgamation or a single converged regional bloc, but towards greater diversity of hybrids with mutually fuzzy boundaries, arranging component pieces in ever new combinations underpinned by increasingly intense regional relations' (Tussie 2009: 185-186).

From another perspective, one based on European experiences - and taken originally without any reference to Latin America - Hofmann and Mérand argue in favour of differentiated multilateral cooperation and 'institutional elasticity', which can foster peaceful and stable interstate relations within a region and minimise the risk of zero-sum politics unfolding. In their view, 'outright bargaining failures become less likely as member states have the flexibility to opt out of certain institutionalised policy domains or they can push for their preferred policy preferences in another institution' (Hofmann and Mérand 2012: 134-135). The authors refer to a European-style variable geometry, where no state 'feels forced to belong to the entire club, and hence is more willing to invest in the policy areas that are close to its interests' (Hofmann and Mérand 2012: 137).

This concept can also be applied to Latin America. Sanahuja (2010: 110) emphasises the point that the Constitutive Treaty (Article 13) of UNASUR explicitly opens up the possibility of a variable geometry-type architecture being constituted in South America. Chilean Foreign Minister Heraldo Muñoz explicitly mentioned the concept of a 'multispeed Europe' ('el concepto de la Unión Europea de las "velocidades diferenciadas") in one of his first public declarations in 2014.

The proliferation and overlapping of regional organisations are phenomena closely interconnected. The question of why regional organisations overlap is related to that of why new regional organisations are created and/or of why they later expand their mandate. Why do states/governments create or join a (new) regional organisation? They do this essentially because they think that they can benefit from their membership in it, or because they want to avoid any expected negative externalities of not being a member. They join different organisations because these bodies are focused on varying topics and because they create more arenas for their strategic projects to be realised in. In Latin America/ South America most regional organisations were first created to promote new regional projects or objectives that had not yet been realised by the existing regional organisations. They were reactions to new challenges (or the zeitgeist), such as the expansion of integration schemes in different world regions in the 1990s or the emergence of a new economic paradigm (for example 'open regionalism'). Regional organisations are newly created and survive when they serve the conflicting strategic interests of the various state actors involved in them (Hurrell 1998). 


\section{UNASUR}

\section{P O L I T I C A L O U T L O O K}

UNASUR: As new building block in the regional architecture.

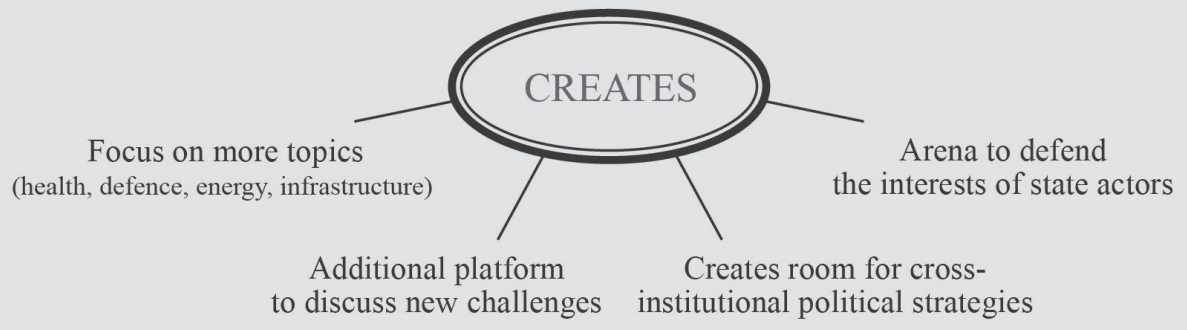

Source: Authors' own elaboration.

Because of the competition and overlapping of regional organisations, it makes no sense to look at them in isolation, 'thus neglecting the specific properties of an institutional architecture (that is, how different regional organisations are assembled together) and the impact that these properties have on regional order' (Hofmann and Mérand 2012: 133-134). In the end, the whole architecture - that is, the combination and interaction of different regional organisations in Latin America - is more important than its parts - that is, individual regional organisations. As will be appreciated in the analysis of the Argentinean support to UNASUR, focusing on one isolated regional organisation might lead to inaccurate conclusions about the state of regional integration. Consequently, it makes more sense to discuss the entire regional architecture rather than to investigate separate regional organisations. In this vein, Van Langenhove (2012: 26) persuasively argues in favour of widening the research agenda on regional integration, with the objective of directing attention to the study of intraregional processes, because 'unlike states regions and regional arrangements can overlap. This has consequences for regional integration as several of such processes may occur simultaneously in a given geographic area.'

\section{Regionalism is what actors make of it}

In the studies on regional integration, very often an approach predominates that evaluates the newly created regional organisations only with regard to their coherence and efficiency - and whether they correspond or not to a pre-established model of integration (specifically, that of the European Union). This approach is inherently flawed, because the 
institutional design of a particular regional organisation reflects the interests and strategies of its founding members. What may be dysfunctional from a purely organisational viewpoint may be functional from the standpoint of the member states (or some of the member states at least). In a similar way, one has to address the fact that many regional organisations overlap with regard to their constituent members and/or mandates. What might be a problem from an organisational perspective can actually create room for strategic action by the individual member states. In general, for the member states the overlapping of regional organisations is not a problem - quite the contrary, it creates the opportunity for cross-institutional political strategies to be pursued.

Sanahuja (2012: 25) writes that through UNASUR 'the aspirations of Latin American regional integration are redefined in a South American geographical and ideational framework.' Regions and regional projects are historically contingent and changing social constructs. There is not one prefabricated model of what constitutes a region. Critics of Latin American regionalism often start with a narrow definition of regional integration, or lambast Latin American governments for failing to deliver something that they never actually promised or aspired to creating in the first place.

Alluding to the title of Alexander Wendt's famous work, Riggirozzi and Tussie (2012: 3) write that a 'region is what actors make of it.' This article shares the outlook that one should take seriously the statements, declarations, and proposals of the actors involved in regional projects, and furthermore should not ask for the delivery of goods never promised by those participating in them - in our case, Latin American governments. However, there is a major bias to be found in many recent analyses of current Latin American regionalism. These start first with a preconceived notion of what regionalism should be, and normally end up advocating a narrow model of European-style integration that includes strong supranational institutions and the transfer of sovereignty. For example, Malamud and Gardini (2012: 130) posit that 'Latin American states continue to establish regional organisations because their leaders know that sovereignty is not relinquished by signing papers. Rather, regionalism is a foreign policy resource used to achieve other ends such as international visibility, regional stability and regime legitimacy.' One might ask what is problematic about these self-declared goals; seemingly, their only 'flaw' is that they do not correspond to the EU model.

Although the European experience of regional integration is unique, many authors often take that continent as the 'gold standard' of regional integration (Sbragia 2008: 33). Subsequently, they come to the unsurprising conclusion that regional experiences outside of Europe do not constitute genuine integration. A good example of this approach is the article by Andrés Malamud and Schmitter, who start with the statement that they understand integration in European terms as a process in which nation-states voluntarily mingle, merge, and mix with their neighbours so as to lose the factual attributes of sovereignty. Further, they argue 'that they do so by creating common and permanent institutions capable of making decisions binding on all members' (Malamud and Schmitter 2011: 143). From this perspective, CAN and Mercosur have made little progress towards integration. Both authors are strictly against a softening or changing of the definition of regional integration because they fear an overextension (conceptual stretching) of the term. In their 
view, 'regional integration should be conceptually differentiated from simple, that is, uninstitutionalised and usually erratic, regional cooperation or collaboration' (Malamud and Schmitter 2011: 143). There seems to be a very strong bias here against all kinds of regional integration and cooperation that do not strictly resemble the European patterns. Consequently, Malamud and Schmitter (2011: 143) disagree that there might be 'a distinctive "Latin American" (or, for that matter, "Asian" or "African") pattern of integration that may not resemble the European "institutional" one, but nevertheless is capable of resolving regional problems, asserting regional cohesion and building regional identity.'

Some Latin American authors however articulate a totally different vision of integration. In the view of the Argentinean economist Aldo Ferrer (2013), the key to successful integration does not rest in the delegation of sovereignty to supranational communitarian institutions. For him, the experience of the EU demonstrates that the concession of sovereignty results in the subordination of the weaker member states to the hegemonic power of the stronger ones. Therefore he argues in favour of an integration that is not based on the transfer of sovereignty, but rather in the solidary construction of sovereignty - a state of being that is still missing for many Latin American states in certain issue areas. Thus for Ferrer, integration consists in the complementation and extension of national sovereignties. For Van Langenhove (2012: 20), meanwhile, 'regions can take over or complement state actorness.'

Public opinion surveys conducted in the region to date have corroborated the preference for a uniquely Latin American form of integration; people there are not interested in the creation of supranational institutions and in relinquishing sovereignty. In general, Brazilians, Chileans, Colombians, Ecuadorians, Peruvians, and Mexicans do not place great importance on the promotion of regional integration as a foreign policy objective (Maldonado 2012). Rising powers such as Brazil, China, India, and South Africa do not promote an EU-type model of regional integration (Fawcett 2013). Also, regional secondary powers such as Argentina, Colombia, and Venezuela (in the case of South America), are not keen to relinquish sovereignty rights. Against the will of these countries and without their participation, it would be impossible to create this kind of institution in their corresponding regions. One should also mention that the euro crisis has seen the EU become a less attractive role model. Furthermore, the EU has also demonstrated that a risk exists of estrangement between the citizens of member states and the supranational institutions governing them. One should not forget that integration is not an end in itself; its success and institutional arrangements depend on the interests of the participating states and of those states' citizens. The EU is thus not always seen as the global benchmark for integration processes.

Starting from this broader vision of Latin American regionalism, in the next sections the paper analyses the position and strategy of the Argentinean government in the formation and construction of the current regional architecture in South America, with a special focus on UNASUR and the interaction of this new South American organisation with other regional actors, organisations, and projects. To what extent, then, does the current regional architecture in South America reflect the interests and foreign policy priorities of Argentina? There is a predominant view among academics (Amoroso Botelho 
2008; Luchetti 2015; Botto 2015) that Argentina supported from the very beginning the creation of UNASUR. In fact, this was not the case. There is another such perspective that advances the idea of Argentina's 'subordination' in this context to Brazil's interests (Merke 2009; Bernal-Meza 2008; Miranda 2015); the reality, however, does not accurately reflect that interpretation either. Finally, they are those scholars who emphasise Argentinean resistance to the UNASUR project (Daudelin and Burges 2011).

Nevertheless, all these interpretations miss the point that the official Argentinean position was not consistent, uniform, or linearly evolving; on the contrary, it was dynamic, characterised by twists and turns, by moments of tension, and especially by a relatively enduring tendency to distrust the South Americanisation project. The analysis here will be focused on the period 1999-2008, being divided into two sub-periods: one extending from the accession to power of the Alianza para el Trabajo, la Justicia y la Educación (Alianza) up until the last days of Eduardo Duhalde's government (1999-2003), the other spanning the time from the beginning of the presidency of Néstor Kirchner up until the signature of the Constitutive Treaty of UNASUR (2003-2008). Notwithstanding government changes, during the whole period the South American project was neither the priority nor the first choice of the Argentinean government. With that in mind, why did it finally consent to the creation of UNASUR? In the next section an answer will be given to this riddle.

\section{Rejecting the South American option in a uniaxial period}

The analysis starts with the 1999-2003 sub-period. It will be structured along the four conceptual dimensions that characterise and capture Argentinean foreign policy at this time: uniaxiality, crisis, South Americanisation, and domestic-foreign policy boundaries.

Uniaxiality. At the beginning of this period, Argentina's regional priority was the Southern Common Market (Mercosur), and it was characterised by an approach one might describe as 'uniaxial'. This kind of integration process approach is structured around one thematic axis, from which spillover effects to other areas are to be expected. The economic-commercial axis marked both the orientation of Mercosur and the foreign policy of Argentina. Of course, this integration approach did not inhibit other topics from being put onto the regional agenda. It is also important to emphasise that economics cannot be separated from politics. The economic uniaxial design of Mercosur was the result of the decisions taken by member countries, choices that expressed their priorities with regard to the regional agenda and the legal and institutional architecture of that block. The focus on the economic axis was so pronounced that Argentinean Minister of Finance Domingo Cavallo once argued that 'está agotado el modelo de relacionamiento comercial con países que se dan el lujo de hacer lo que quieren con sus monedas' (Clarín 2001: 27 October). Despite some progress made over the definition of common positions between the various Mercosur countries, ${ }^{1}$ Cavallo reduced regionalism to essentially short-term negotiations on trade and financial, especially debt-related, issues. Changing this orientation required attendant political will and the multidimensional crisis that culminated in $2001,{ }^{2}$ which created a demand for political change. 
Crisis. Between 1999 and 2003 a vicious circle existed between the internal crisis and intraregional discrepancies, circumstances that were also influenced by the behavioural choices of extra-regional actors. This led the Argentinean government to take a new look at several issues, among them regional integration. This scenario was propitious for a reconsideration of Mercosur's uniaxial orientation. However the ways in which the reconceptualisation of regional integration was proposed were not uniform in nature. Different actors attempted to impose their own divergent visions, leading to a process full of marches and counter-marches, convergences and divergences. The result of this was that during this period diverse approaches to how to broaden and deepen regional linkages emerged side-by-side.

In this regard, the discussion that took place about what the best strategy would be for relaunching Mercosur is quite illustrative. Concepts such as 'regeneration', 'new commitment', or 'change' were used sometimes as synonyms, sometimes also as antonyms, in the speeches given at the time by members of the Argentinean political elite. Different politicians embellished these concepts with their own specific ideational content. In 1999, former president Carlos Menem argued that taking the path towards a single currency was vital for regional integration. He identified the United States dollar as the ideal common currency. In his words, dollarisation would benefit 'la gente' (La Nación 1999: 2 January).

In early January 2000, meanwhile, Beatriz Nofal, Member of Parliament from the Alianza, emphasised the need for a new political commitment by the parties to achieve integration. However, her proposed recipes continued to focus on the economic agenda: the guarantee of free intra-Mercosur trade, compliance with the common external tariff, harmonisation of regional tax incentives, settlement of commercial disputes, and better macro-economic co-ordination (La Nación 2000: 2 January). Years later, and following this line of argumentation, a former minister of foreign affairs emphasised that in the context of pronounced Brazilian protectionism 'el relanzamiento del Mercosur tenía, para mí, una especificidad que era un mayor equilibrio de mercado' (Interviewee 12014 ). After Lula da Silva was elected as the new president of Brazil in 2002, Duhalde's minister of foreign affairs, Carlos Ruckauf, declared that '[1]as puertas del mundo podrán abrirse para el Mercosur gracias a la vocación por la unión aduanera del sur que demuestra el presidente electo brasileño Luiz Inacio Lula da Silva' (Clarín 2002: 28 November). A former Argentinean President stated, some time afterwards, that the relaunch should have gone in the direction of an imitation of European institutions: '[T]eníamos que crear las estructuras que ya tenía la Unión Europea’ (Interviewee 2 2014).

South Americanisation. Concurrent with the Argentinean crisis, and while searching for the appropriate channels through which to reconfigure Mercosur, Brazil launched once more its proposal to create a South American organisation. The official Argentinean positions regarding this initiative ranged from disinterest to giving a lukewarm and unspecified commitment to it. The South American Summit held in Brasilia in 2000 was illustrative of this Argentinean ambivalence. On that occasion, the De la Rúa government was overtly reticent about endorsing an integration path that excluded other states of geostrategic importance such as Mexico or the United States. ${ }^{3}$ Because Mexico was not invit- 
ed, the Argentinean Ministry of Foreign Affairs delayed the confirmation of its country's participation in the summit meeting. The Argentinean foreign minister even requested an exclusive meeting of the 'group of four' (Argentina, Brazil, Chile, and Mexico) prior to the summit. The deliberate exclusion of Mexico was perceived by many within the Argentinean government as being a part of Itamaraty's strategy for strengthening Brazil's own position as the regional leader.

For that reason, the Argentinean government preferred a variable geometry of regional integration - supporting, inter alia, the Initiative for the Integration of the Regional Infrastructure of South America (IIRSA) and the establishment of a subcontinental free trade area complementary to the Free Trade Area of the Americas (FTAA), to be realised by 2002. This was in line with the country's foreign policy priorities: Mercosur and the FTAA. The Argentinean representatives rejected any initiative that would necessitate making strong institutional and political commitments. This was the case when Venezuelan President Hugo Chávez proposed creating a South American confederation, with the objective of advancing from an essentially economic integration scheme towards a specifically political regional project. However, Argentina was not the only country that rejected the Venezuelan plan: the main opponent to it was Brazilian president Fernando Henrique Cardoso, who argued that the Rio Group already existed to deal with regional political issues, and that it did not make sense to have two forums addressing the same topics (Folha de São Paulo 2000: 2 September).

This constellation was no different in 2002 either, when the second South American presidential summit took place in Guayaquil. This meeting was characterised by the participation of many weak or lame duck governments, and by the absence of some key presidents. At the summit, the Duhalde government expressed its intention to advance with the South Americanisation of regional integration. It signed the Guayaquil Consensus on Integration, Security, and Infrastructure for Development, which, while expanding the regional agenda, was essentially only a declamatory document in practice. However, the Duhalde Administration was a government by default, with low legitimacy both internally and externally. In fact, when it had the chance to support specific regional public policies, it voted against these initiatives. The Argentinean representatives vetoed projects such as the creation of an International Humanitarian Fund (IHF) - conceived of as a counterbalance to the IMF - and the formation of an organisation of South American oil-producing countries (El País 2002: 30 September). All of these measures had originally been proposed by Venezuela.

Domestic-foreign policy boundaries. Argentina's position in regard to Mercosur and to the South Americanisation proposal was shifting and incoherent at the time, because this was a period full of political and economic turbulences. Governments changed frequently, and so did the relationships between them and both external and internal actors. It is difficult to maintain a consistent official position when the foreign and domestic environment is in flux. The governments of both De la Rúa and Duhalde were restrained by external stakeholders, which contributed to the intensification of the national crisis. The global financial crisis and the complicated relations with foreign governments - especially with Spain and the US, as leading investors in the country - and with international financial 
institutions - such as the IMF, World Bank, and Inter-American Development Bank - defined Argentina's political priority at the time as being 'do not implode.'

External pressures interacted with internal dynamics, affecting and restricting the availability of Argentinean foreign policy options during this critical period. Intergovernmental bickering and government-opposition conflicts were of particular relevance here. From 1999 to 2003, the policy with regard to Mercosur and the South American alternative was conditioned above all by domestic politics. Over time, divergences and tensions about how to position Argentina in relation to these projects emerged both within the government and among the opposition as well. Within this process, the positions were often antagonistic. This was visible within the Alianza, due to the polarisation between Minister of Foreign Affairs Rodríguez Giavarini and Minister of Finance Cavallo. Rodríguez Giavarini defended the pursuing of a 'concentric' strategy, starting from the basis of a strong alliance formed with Brazil, in order to strengthen Mercosur and to ensure Argentina's immersion into the world at large through this regional alliance.

In contrast, Cavallo advocated taking a very light variable geometry approach, while co-ordination through Mercosur would ideally be minimal and flexible. 'Lo mejor es seguir la vía chilena: negociaciones bilaterales en frente múltiples,' he argued in 2001 (Clarín 2001: 7 May). There were multiple and diverse options and formulas proposed for Argentina's international position. The country should not be restrained by the Mercosur. A similar situation arose during the years of the Duhalde Administration, when Foreign Minister Ruckauf was very critical of Brazil. Less than two years before he assumed this position, he had even asked for the suspension of the Asuncion Treaty (La Nación 2000: $15 \mathrm{March}$ ). On the other hand, the president was an advocate of the bilateralisation of regional integration - based on the assumption that Argentina and Brazil were Mercosur's heartbeat - as an initial step towards further improvement in the relationships with other Latin America countries.

Sectorial demands and pressures fuelled and reinforced these intragovernmental discrepancies. During this period, economic conflicts evolved in sectors such as those of livestock, agriculture, textiles, and the automobile industry, which involved interest groups, private companies, trade unions, and social and political actors. These conflicts put pressure on Argentina's uniaxial agenda, and had a negative impact on the country's relations within the region.

\section{Multiaxial paths: From divergence to convergence}

While until 2003 mistrust had characterised Argentina's position with regard to the South American vision, one can in fact assert that, from then up until 2008, the situation did not substantially change either. It is true that in 2008 President Cristina Fernández signed UNASUR's Constitutive Treaty, but this decision stood at the end of a complicated process - one with many ups and downs, as well as conflicts and tensions, in the relationship between Argentina and Brazil. As in the previous section, the analysis is organised according to four dimensions that mark the general tendencies in Argentinean foreign policy at the 
time: multiaxiality, the erosion of uniaxiality, South Americanisation, and domestic-foreign policy boundaries.

Multiaxiality. This concept characterises integration processes that evolve along multiple axes in parallel. The involved governments do not privilege one central axis, but rather prefer to advance simultaneously in several different areas. These often include trade and financial cooperation, but can also involve such domains as poverty reduction, the fight against social exclusion and marginalisation, the eradication of hunger, the improvement of health services and of education, as well as cooperation over defence and security issues. In the multiaxial model, the integration process does not necessarily always advance along the same axes, simultaneously, or with the same intensity and speed. The article will demonstrate how between 2003 and 2008 the Argentinean government preferred a multiaxial approach, with this being true both when it negotiated over the future of Mercosur and during the creation of UNASUR.

The erosion of uniaxiality. Argentina played an active role in the striving for a multiaxial Mercosur. This can be substantiated primarily on the discursive level, through the witnessed promotion of ideas such as a 'Mercosur reforzado' during the time of the Duhalde Administration (Clarín 2003: 5 February) or a 'Mercosur abarcativo' (La Nación 2003: 19 June) in the Kirchner years. During the 2003 presidential campaign, Néstor Kirchner had raised this argument with the objective of differentiating himself from Carlos Menem with regard to the international immersion of Argentina: via his party platform he asserted that the consolidation of Mercosur would be a priority of his government if elected. With this objective in mind, between 2003 and 2008 both he and Cristina Fernández de Kirchner endorsed a wide range of projects that made the block more multiaxial in nature.

Several examples exist of how the Argentinean government was now actively promoting a multiaxial regional integration scheme: the promulgation of the '2006 Objective', with 32 thematic areas and the inclusion of topics related to commercial, financial, institutional, industrial, military, police, social, or energy issues; the 'Buenos Aires Consensus', an expression of the Argentinean-Brazilian bilateralisation of Mercosur (with 22 constituent points, encompassing issues in areas such as education, health, social inclusion, science and technology, culture, and environment); and, the 'Work Program 2004-2006, designed with the objectives in mind of an 'economic-trade Mercosur', a 'social Mercosur', an 'institutional Mercosur', and a 'new integration agenda'. Likewise, the Argentinean government repeatedly pressed for a more solid and entrenched Mercosur. In that direction, it supported such measures to further institutionalise the regional integration scheme as: the rules of procedure of the Political Consultation and Coordination Forum; the regulation of the Olivos Protocol for the settlement of disputes; the Permanent Review Tribunal for Dispute Settlement; the Commission of Permanent Representatives; and the MERCOSUR Parliament. It also emphasised the necessity of looking ahead and thinking about future projects, which were expected to range from the creation of a common currency, a Regional Monetary Institute, a Social Institute, a Democracy Observatory, a fund to finance the education sector, and a Bank of the South to a 'Gran Gasoducto del Sur.4

Moreover, during this period, Argentina, Brazil, Paraguay, Uruguay and Venezuela articulated a strong position against the FTAA, a uniaxial regional integration project un- 
der the United States' leadership. This attitude was explicitly visible in 2005 during the 4th Summit of the Americas in Buenos Aires. In the words of a former Argentinean minister of foreign affairs, this was a 'historical day (in Spanish 'día histórico'). Some interpretations focus on the ideological rupture as one of the relevant factors that paralysed the FTAA negotiations (Nelson 2015). It was indeed a key factor. In the opinion of the former Argentinean minister, 'el fin del ALCA' (buried during the Buenos Aires summit) 'es el comienzo de la Unasur.' Nevertheless, according to him, the main reasons for the rupture were associated with commercial interests, especially with the fact that United States is a huge food exporter. From this perspective, the US represented 'un competidor natural' for Argentina, he said (Interviewee 12014 ).

South Americanisation. Parallel to its endeavours towards the multiaxialisation of Mercosur, Argentina also supported that body's enlargement. This was noticeable when in 2003 Argentina supported the associated membership of Peru, as well as the negotiation of a free trade agreement with the Andean Community (which was formalised in 2005). Moreover in 2006, the Protocol of Accession of Venezuela was signed. Thus, between 2003 and 2008 Argentina promoted the expansion of Mercosur through the inclusion of different states in it, some with the status of associated members - such as Bolivia, Colombia, Ecuador, and Peru - while others - such as Venezuela - sought to become incorporated as full members.

However, while Argentina promoted the consolidation of a multiaxial, deeper, and broader Mercosur, the proposal to establish a new South American regional organisation also progressed. There were certain moments when the Argentinean government openly supported this initiative. This was the case when the logic of Argentinean-Brazilian regional bilateralism prevailed, as during the Mercosur summit in Montevideo 2003, at which President Kirchner referred to the construction of a South America with one voice (La Nación 2003: 16 December). This happened again in 2006, in the time period between the meeting of the South American Community of Nations (CSN) in Brasilia and the Mercosur summit in Córdoba, Argentina. Argentina's support for the South American option was directly associated with the country's honeymoon periods with Brazil. When the relations between both governments flourished, Itamaraty's dream of regionalizing integration - with the objective of including all South American countries - often received the backing of the Argentinean authorities. There were several situations in which Argentina ended up backing the institutionalisation of the South America project: this was explicitly the case during the 2004 Cusco summit - when the constitution of the CSN was initiated - and during the 2008 presidential summit in Brasilia - when both governments signed the UNASUR Constitutive Treaty.

Beyond these positive signals given, however, there was still reluctance on the Argentinean side to fully endorse the South America project. Argentina's enlargement perspective for Mercosur was not limited to South America. Even when the Argentinean government distanced itself temporarily from countries such as Cuba or Mexico, this did not imply that it had also renounced its Latin American vision for an enlarged Mercosur. After intensive fieldwork ${ }^{5}$ investigating the Argentinean government's position, it can be confirmed that South Americanisation was generally interpreted by the Argentinean au- 
thorities as a shoe made for Brazilian feet. From this perspective, the South America project would in fact contribute to the further isolation of countries such as Cuba - and to the permanent exclusion of other countries from the bargaining table too, ones that, as in the case of Mexico, might become counterweights to Brazil. Therefore, Argentina supported the Cuba-Venezuela alliance, the origin of the Bolivarian Alliance for the Peoples of Our America (ALBA). This alternative regional project was perceived not only as a rejection of the contents and purposes of the FTAA (Kellogg 2007) but also as a way to overcome Cuba's isolation (ALBA 2004)

'Lo que te quiero decir es que la posición de Argentina... era de no entusiasmo, pero de acompañar,' explained a former high-ranking member of the Argentinean Ministry of Foreign Affairs regarding the UNASUR Constitutive Treaty negotiation. From his point of view, Itamaraty's intention of achieving a permanent seat for Brazil in the United Nations Security Council aroused suspicion at the time. He argued that, for Brazil, 'el negocio de UNASUR era sudamericanizar la región con un proyecto a 10, 15 o 20 años para cuando negocie su ingreso al Consejo de Seguridad.' This would be an excellent opportunity for Brazil to present itself as 'yo soy Sudamérica' (Interviewee 3 2014). 'A nosotros nos resultaba poco natural un recorte sudamericano, para nosotros el recorte era América Latina, ese era nuestro recorte donde nos sentíamos cómodos', added later another important Argentinean negotiator during the creation of UNASUR (Interviewee 4 2011).

From the Argentinean perspective, it was important to build up a counterbalance to Brazil. 'Sentía que si la mesa era únicamente entre Brasil y Argentina, la Argentina perdía; en cambio sí se triangulaba - y nosotros teníamos tan buena relación con México- desbalanceábamos a Brasil,' said the same diplomat (Interviewee 4 2011). The signing of an Argentinean-Mexican strategic partnership agreement in 2007 - which was approved almost simultaneously with the negotiations of the Strategic Reflection Committee responsible for the elaboration of a draft for the UNASUR statute and the subsequent inclusion of the category of 'associated states' in the Constitutive Treaty (which unlocked the gate for the future incorporation of other Latin American countries) - reflects the Argentinean government's strategic objective of balancing.

Domestic-foreign boundaries. The South Americanisation dynamic was progressively interfering with the multiaxial profile that had initially been planned for Mercosur. The projects of the CSN and subsequently UNASUR coincided with the diffusion of a regional integration concept that operated simultaneously on multiple axes. Nevertheless this multiaxial approach was constantly undermined by ongoing conflicts over economic and trade issues, occurring both internationally and domestically.

Starting with the international level, as during the 1999-2003 cycle, between 2003 and 2008 economic and trade conflicts proliferated. Notwithstanding the 'buena sintonía' between Duhalde and Lula, both political leaders were in practice unable to avoid sectorial economic pressures (such as from sugar, meat, and wool producers) damaging the relationship between Buenos Aires and Brasilia. This situation had spillover effects on different regional arenas. There was a tendency towards uniaxiality witnessed again throughout the years that followed, leading to tensions with, among others, Bolivia, Chile, Paraguay, and Uruguay. This trend was reinforced by debates emerging about the current asymme- 
tries in the Mercosur region, ranging from concerns about commercial and economic topics to geostrategic issues. Even areas where there had been advances made with regard to the different countries' capacities to influence the regional agenda were now questioned. The Argentinean-Brazilian bilateralism within Mercosur - as in the time of the Buenos Aires Consensus - was criticised by Paraguay and Uruguay because they felt excluded from the process of defining Mercosur's priorities.

It should also be mentioned that the Argentinean government's position with regard to both Mercosur and UNASUR was also influenced by the other international negotiations in which it was concurrently taking part. To take an example, although the Argentinean government still adhered to the formula ' $4+1$ ' different moments its relationships with the countries of the region were affected by these dialogues with non-South American actors. Sometimes these negotiations had an integrative impact on Mercosur, sometimes they bolstered centrifugal forces within the organisation. This could be seen not only in the position adopted in the negotiations over the FTAA, but also in the negotiations with the EU, the IMF, the World Bank - or even in those with India, Japan, and Korea. Thus, on numerous chessboards the ' $\mathrm{X}+1$ ' formula was constantly challenged by the ' $1+1$ ' alternative - as preferred by other states such as Chile.

The disruption caused by external nuisances was reinforced by a number of domestic factors and actors too. These included intergovernmental conflicts, as well as the friction arising between government sectors and the opposition. One of the key elements that needs to be taken into account in order to understand the Kirchner government's resistance to the South America project is the fact that the latter was directly associated with former president Duhalde's strategy to become a regional leader. Duhalde was a strong supporter of Lula (and of Chávez) with regard to the constitution of a CSN. Although initially Duhalde received the explicit support of all Mercosur members in heading the Committee of Permanent Representatives, the progressive deterioration of his relationship with Kirchner had a direct impact on the Argentinean government's position with regard to the South America project.

The 2004 Cusco Summit was the most illustrative example of the repercussions of this ongoing conflict between Kirchner and Duhalde. From his position in Mercosur, Duhalde had been one of the principal promoters of the summit. However, in the end Kirchner did not even participate in the event. In order to better understand this dispute, one should know that both politicians were in direct confrontation with each other over the control of the Justicialist Party. Four years later, meanwhile, the relatively brief stopover of Cristina Fernández at the 2008 South American presidential summit, which in the end gave birth to UNASUR, must, though, be understood in the context of the severe Argentinean domestic crisis that arose in relation to the controversial tax imposed on the export of certain cereals and oilseeds.

\section{Conclusion}

With the signature of UNASUR's Constitutive Treaty in 2008, the Argentinean government finally supported the creation of a South American regional organisation. This it did 
in a period full of new and competing regional projects. UNASUR embodies the idea of unity and harmony, but it was born also as a reaction to ongoing conflicts. It can be argued that conflict is an incentive for co-operation. At the time when UNASUR was created, several subregional conflicts still persisted. These involved variously: Ecuador, Venezuela, and Colombia; Argentina and Uruguay; Paraguay, Argentina, and Brazil; Paraguay and Brazil; Bolivia and Brazil; Chile and Peru; Chile and Bolivia; Guyana and Venezuela; and other conflicts that meanwhile confronted Guyana and Suriname. Thus, the creation of UNASUR was not an expression of perfect and permanent harmony; its existence does not necessarily indicate ideational conformity either. In that sense, when Argentina acceded to the new regional organisation, it decided to participate in a process that involves a plurality of actors with often divergent interests. For instance, countries such as Chile, Colombia, and Peru have previously signed free trade agreements with extraregional actors like the US. In fact, at the time of UNASUR's inception, the Pacific Alliance already existed - but the latter body was then still without a name and a formal structure.

Argentina joined UNASUR by supporting the flexible institutional and 'utilitarian' (Nelson 2015: 184) model promoted by Brazil, meanwhile discarding the institutionalizing' proposal promoted by countries such as Venezuela and Ecuador. Argentinean government representatives perceived the new organisation as an opportunity for advancing certain goals regarding the definition of a regional agenda, specifically by exercising intellectual leadership within UNASUR.

Figure 3: Argentina's position in regard to the South Americanisation of regional integration 1999-2008

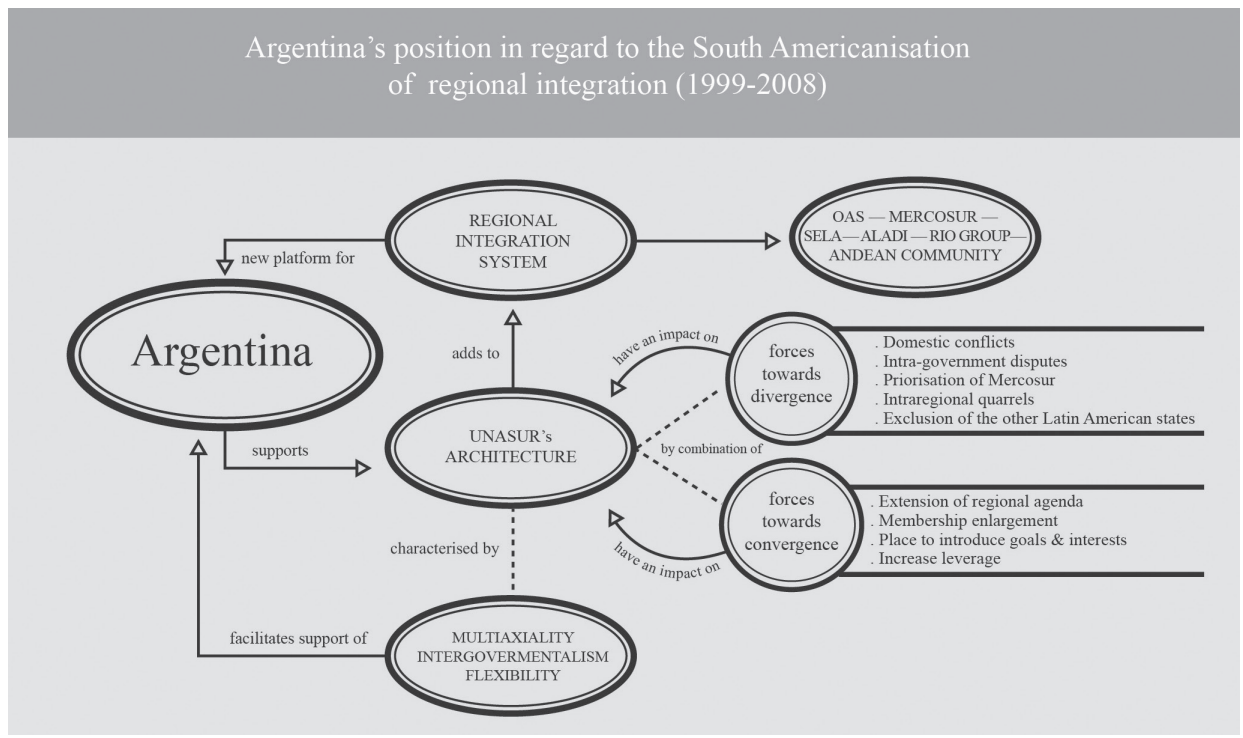

Source: Authors' own elaboration. 
For the Argentinean government, it was important to ensure that it was not too restrictive in its foreign policy. Flexibility, gradualism, and simplicity were the cornerstones of the new regional organisation. In the end, UNASUR created a win-win situation for Argentina and Brazil. Both the 'Mercosur ampliado' option prioritised by Buenos Aires and the South American alternative promulgated by Brasilia were based on the notion of 'no restraints.' The result was the variable geometry codified in the UNASUR Constitutive Treaty.

UNASUR is a platform that, thanks to its profile and institutional architecture, allows the Argentinean government to define and put into practice its own regional integration agenda without any major foreign policy restrictions. The institutional design of UNASUR guarantees that the Argentinean government can freely develop its relations with other regional actors, and regardless of whether they are situated inside or outside of South America's geographical borders. UNASUR thus cannot be understood or studied without taking into account the whole regional architecture, both in the Latin American and the South American regions.

Mercosur is still the core element of the Argentinean-Brazilian alliance, and the main platform for Argentina's regional strategy in economic, political, and social terms. UNASUR constitutes an additional regional forum in which it is possible to cooperate on other issue areas, such as those of defence, infrastructure, health, science and technology, or finance. Moreover, the whole regional architecture also includes other entities such as OAS, the Rio Group (now CELAC), and ALADI. Their importance varies in terms of territorial reach and political conjunctures. For instance, for the Argentinean government in 2008, the OAS was still perceived as an important multilateral forum for dialogue - one with a focus on human rights and the Malvinas dispute - with the US, but also as a political arena in which to balance not only against the power of Washington, but also against that of some South American partners such as Brazil or Venezuela. Moreover, it is a forum from which Mexico is not excluded. To take another example, the Rio Group played an essential role in the resolution of the 2008 Ecuador-Colombia-Venezuela crisis. For Argentina, it has been important to include allies such as Cuba - which is not part either of UNASUR or of OAS - in this regional mechanism of political consultation and coordination.

This complex regional architecture increases institutional flexibility, and enables Argentina to act in multiple arenas of dialogue and co-operation. This regional architecture encompasses all countries of the Americas, but also smaller regional subunits such as Latin America, South America, or the Southern Cone - as well as a broad spectrum of thematic axes. The creation of new regional organisations has led to an overlapping of memberships in them, and in some cases also of mandates -especially between regional organisations with different or overlapping geographic reaches. Whether the overlapping of regional organisations is harmful or beneficial ultimately depends on what the involved actors make out of them. What might be seen as problematic from a purely institutional point of view can in fact be an optimal strategic outcome, when taking into account the strategic interests of the various state actors involved.

This article has demonstrated that the institutional structure of UNASUR is not the result of some distorted design or organisational defect. Nor can one attribute its nature 
to an insufficient or superficial reading of the textbooks on European integration. Instead, it responds to the - sometimes contradictory - interests of the organisation's designers, in this case study, Argentina. UNASUR is not merely another instance of institutional chaos or another piece of spaghetti in the bowl, but rather the result of a conscious decision to add a further layer to the institutional architecture of South America. It would be fascinating to have available similar case studies on the foreign policy strategies and interests of other South American countries in the process of UNASUR's formation; hopefully the literature will furnish us with such works in the near future.

\section{Notes}

1 For example, during the summit of the World Trade Organization held between 9 and 14 November 2001 the Mercosur countries were able to define a common position when they claimed that economically more advanced countries should eliminate their subsidies to the agricultural sector.

2 Until then, an economic recession had been affecting Argentina ever since the mid-1990s; in 2001 these economic problems evolved into a multidimensional political, social, and cultural crisis. This turn of events culminated in the resignation of President De la Rúa, and in the emergence of a temporary power vacuum in the country.

3 At that time, the US was a key player in the negotiations taking place with multilateral credit agencies such as the IMF or the World Bank.

4 These projects were proposed by Venezuela, with some not being restricted to Mercosur but also involving other South American countries.

5 This fieldwork involved conducting 32 interviews with stakeholders and important protagonists from the period under analysis. These were realised between 2010 and 2014. Informal meetings with officeholders from the Ministry of Foreign Affairs, Ministry of Defense, and Ministry of Economy, as well as with representatives of nongovernmental organisations, complemented these interviews.

6 This formula refers to the fact that the four Mercosur member countries have continued to negotiate as a block with other states or regional organisations - such as, for example, with the rest of the Americas in the FTAA process.

\section{References}

ALBA. 14 December 2004. Declaración Conjunta Venezuela-Cuba. Portal Cuba. Available at: http:// www.cuba.cu/gobierno/discursos/2004/esp/d141204e.html [accessed 14 December 2016].

Batista, Paulo Nogueira. 1994. 'O Mercosul e os interesses do Brasil', Estudos Avançados 8(21): 79-95. Bernal-Meza, Raúl. 2008. 'Argentina y Brasil en la Política Internacional: regionalismo y Mercosur (estrategias, cooperación y factores de tensión', Revista Brasileira de Política Internacional 51(2): 154-178.

Botelho, João Carlos Amoroso. 2008. 'La creación y la evolución de Unasur', Revista Debates 2(2): 299-324.

Botto, Mercedes. 2015. 'América del Sur y la integración regional: ¿Quo vadis? Los alcances de la coopearación regional en el MERCOSUR', Confines de Relaciones Internacionales y Ciencia Política, 11(21): 9-38.

Clarín. 27 October 2001. 'Dichos de Cavallo y de la Embajada'. Clarín. Available at: http://edant. clarin.com/diario/2001/10/27/e-01602.htm [accessed 09 September 2015]. 
7 May 2001. 'Mercosur: polémica en el Gobierno'. Clarín. Available at: http://old.clarin. com/diario/2001/05/07/e-00501.htm [accessed 11 September 2015].

. 28 November 2002. 'Viene Lula y Duhalde apuesta al Mercosur para salir de la crisis'. Clarín: http://edant.clarin.com/diario/2002/11/28/p-01801.htm (accessed 11 September 2015)

5 February 2003. 'Brasil necesita un Mercosur fuerte para luego negociar con EE.UU' Clarín. Available at: http://edant.clarin.com/diario/2003/02/05/e-01601.htm [accessed 12 September 2015].

Daudelin, Jean and Sean Burges. 2011. 'Moving in, carving out, proliferating: The many faces of Brazil's multilateralism since 1989', Pensamiento propio 33: 35-64.

El País. 27 July 2002. ‘Chávez propone crear un nuevo ‘FMI’ y una nueva ‘OPEP’ sólo para Latinoamérica’. El País. Available at: http://elpais.com/diario/2002/07/27/internacional/1027720804_850215. html [accessed 7 August 2015].

Fawcett, Louise. 2013. 'The History and Concept of Regionalism', UNU-CRIS Working Papers $\mathrm{W}-2013 / 5$.

Ferrer, Aldo. 2013. 'Transformaciones de América Latina'. Página/12. Available at: <www.pagina12. com.ar/diario/elmundo/ 4-212708-2013-01-27.html> [accessed 13 February 2013].

Folha de São Paulo. 2 September 2000. 'FHC diverge de Chávez ao abrir reunião'. Folha de São Paulo. Available at: http://acervo.folha.com.br/fsp/2000/09/02/2/ [accessed 21 October 2014].

Genna, Gaspare M and Philippe De Lombaerde. 2010. 'The small N Methodological Challenges of Analyzing Regional Integration', European Integration 32(6): 583-595.

Gómez-Mera, Laura. 2015. 'International Regime Complexity and Regional Governance: Evidence from the Americas', Global Governance 21(1): 19-42.

Hofmann, Stephanie and Fédéric Mérand. 2012. 'Regional Organizations à la Carte: the Effects of Institutional Elasticity'. In Thazha Varkey Paul (ed), International Relations Theory and Regional Transformation. Cambridge: Cambridge University Press. pp. 133-157.

Hurrell, Andrew. (1998). 'Security in Latin America', International Affairs 68(1): 529-546.

Interviewee 1. 1 April 2014. Interview. (N. Comini, Interviewer).

Interviewee 2. 13 September 2014. Interview. (N. Comini, Interviewer).

Interviewee 3. 15 August 2014. Interview. (N. Comini, Interviewer).

Interviewee 4. 25 October 2011. Interview. (N. Comini, Interviewer).

Kellogg, Paul. 2007. 'Regional Integration in Latin America: Dawn of an Alternative to Neoliberalism?’ New Political Science 29(2): 187-209.

La Información. 27 October 2011. 'Piñera: 'Latinoamérica tiene tantas cumbres que parece una cordillera'. La Información. Available at: http://noticias.lainformacion.com/politica/diplomacia/pineralatinoamerica-tiene-tantas-cumbres-que-parece-una-cordillera_DEPlZe1wqN05YiIbfzna22/ [accessed 20 November 2015].

La Nación. 16 January 1999. 'Menem propone como salida que el Mercosur se dolarice'. La Nación. Available at: http://www.lanacion.com.ar/124714-menem-propone-como-salida-que-el-Mercosurse-dolarice [accessed 20 October 2015].

. 15 March 2000. 'Otro ataque de Ruckauf al Mercosur'. La Nación. Available at: http:// www.lanacion.com.ar/9056-otro-ataque-de-ruckauf-al-MERCOSUR [accessed 09 October 2015]. 
. 2 January 2000. 'Relanzar el bloque’. La Nación. Available at: http://www.lanacion.com. ar/33-relanzar-el-bloque [accessed 07 September 2015].

19 June 2003. 'Kirchner y Chávez cerca de un acuerdo'. La Nación. Available at: http:// www.lanacion.com.ar/504912-kirchner-y-chavez-cerca-de-un-acuerdo [accessed 24 November 2015].

16 December 2003. 'Se suma al bloque la Comunidad Andina'. La Nación. Available at: http://www.lanacion.com.ar/555871-se-suma-al-bloque-la-comunidad-andina [accessed 08 September 2015].

Luchetti, Javier Fernando. 2015. 'Political Dialogue in South America: The Role of South American Nations Union', Limits to Regional Integration 95.

Malamud, Andrés. 2013. 'Overlapping Regionalism, No Integration: Conceptual Issues and the Latin American Experiences', EUI Working Paper RSCAS 2013/20.

Malamud, Andrés and Gian Luca Gardini. 2012. 'Has Regionalism Peaked? The Latin American Quagmire and its Lessons', The International Spectator: Italian Journal of International Affairs 47(1): 116-133.

Malamud, Andrés and Philippe C Schmitter 2011. 'The experience of European integration and the potential for integration in South America'. In Alex Warleigh-Lack et al. (eds), New Regionalism and the European Union - Dialogues, comparisons and new research directions. Abingdon: Routledge. pp. 135-157.

Maldonado Hernández, Gerardo. 2012. 'Multilateralismo, integración regional y opinión pública en América Latina: la sociedad es un obstáculo?' In Francisco Rojas Aravena (ed), América Latina y el Caribe: Vínculos globales en un contexto multilateral complejo. Buenos Aires: FLACSO. pp. 477-496.

Muñoz, Heraldo. 2014. 'Convergencia en la diversidad: la nueva política latinoamericana de Chile'. El País. Available at: http://elpais.com/elpais/2014/03/12/opinion/1394642773_153377.html [accessed 01 November 2015].

Merke, Federico. 2009. 'Conclusiones sobre la economía política del regionalismo en Sudamérica', Centro de Estudos de Integração e Desenvolvimento: 1-26.

Miranda, Roberto Alfredo 2009. 'Corolario de Brasil: la Argentina sin poder en el nuevo tablero regional', Relaciones Internacionales: 169-186.

2015. 'Efecto de vecino. El poder de Brasil sobre el regionalismo de Argentina', Invenio: Revista de investigación académica (34): 35--50.

Nelson, Marcel. (2015). A History of the FTAA: From Hegemony to Fragmentation in the Americas. Palgrave Macmillan.

Riggirozzi, Pia and Diana Tussie (eds). 2012. The Rise of Post-hegemonic Regionalism. The Case of Latin America, Dordrecht: Springer.

Sanahuja, José Antonio. 2012. 'Post-Liberal Regionalism in South America: The Case of UNASUR', EUI Working Paper RSCAS 2012/05.

2010. 'La construcción de una región: Suramérica y el regionalismo posliberal'. In Manuel Cienfuego and José Antonio Sanahuja (eds), Una Región en Construcción, UNASUR y la integración en América del Sur. Barcelona: CIDOB. pp. 87-136.

Sbragia, Alberta. 2008. 'Review Article: Comparative regionalism: What might It be?' Journal of Common Market Studies 46: 29-49. 
SELA. 2013. El ALBA-TCP como mecanismo de cooperación de alcance regional. Caracas: Secretaría Permanente.

Tussie, Diana. 2009. 'Latin America: contrasting motivations for regional projects', Review of International Studies 35:S1: 169-188.

Van Langenhove, Luk. 2012. "Why We Need to "Unpack" Regions to Compare Them More Effectively', The International Spectator: Italian Journal of International Affairs 47(1): 16-29.

Weiffen, Brigitte, Leslie Wehner and Detlef Nolte. 2013.'Overlapping regional security institutions in South America: The case of OAS and UNASUR', International Area Studies Review 16(4): 370-389.

\section{About the Authors}

Detlef Nolte is vice-president of the GIGA German Institute of Global and Area Studies and director of the GIGA Institute of Latin American Studies; professor of political science at the University of Hamburg; president of the German Latin American Studies Association (ADLAF) (2010-2016). Research interests: comparative regionalism and regional governance in Latin America; constitutional change and political institutions in Latin America. Recent publications: Nolte, Detlef / Schilling-Vacaflor, Almut (eds.) (2012), New Constitutionalism in Latin America. Promises and Practices, Oxon/New York: Ashgate; Nolte, Detlef / Wehner, Leslie (2016), 'Geopolitics in Latin America, old and new', in: David R. Mares / Arie M. Kacowicz (eds), Routledge Handbook of Latin American Security, London/New York: Routledge, 33-43. https://www.giga-hamburg.de/de/team/nolte.

Nicolás Comini is Director of the Master's programme in International Relations (Universidad del Salvador, Argentina). He has a doctorate in Social Sciences from the Universidad de Buenos Aires. He holds an MA in Latin American Integration (Universidad Nacional de Tres de Febrero) and a BA in International Relations from Universidad del Salvador. His research interests today are in the field of regional integration and international security. His publications include suRamericanizados: la integración regional desde la Alianza al kirchnerismo (2016) and De cadencias y disonancias, representaciones alternativas de la integración regional en el siglo XXI: América Latina, Asia y Europa del Este (2014).

Received on 13 January 2016 and approved for publication on 9 May 2016.

\section{(cc) BY-NC} https://creativecommons.org/licenses/by-nc/4.0/ 
